\title{
Aspects of the modern biogens runoff formation in the central part of the Russian Plain
}

\author{
Sergey Dolgov ${ }^{*}$, Nikolay Koronkevich, and Elena Barabanova \\ Institute of Geography RAS, 29 Staromonetny lane, 119017, Moscow, Russia
}

\begin{abstract}
The removal of biogenic substances (mineral nitrogen and phosphorus) from river catchments and its modern aspects of formation are considered. A rough estimate of the annual water-biogenic balance for the Linda and Kudma river catchments, which are the tributaries of the Cheboksary reservoir, and the river catchments of the Kursk region is presented. It is shown that the diffuse removal of biogens from river catchments exceeds their removal into water bodies with wastewater. Not only anthropogenic, but also natural factors play an important role in the biogens export to the rivers and waterbodies. Resent changes in biogens removal from catchments are assessed.
\end{abstract}

\section{Introduction}

Further water resources development in the central part of the Russian plain, which is experiencing intense anthropogenic pressure, in many cases is complicated by their poor quality. Knowledge of water quality genesis is an important condition for effective water resources management. Despite the fact that quite a large number of studies have been devoted to this problem, the uncontrolled diffuse (dispersed over the territory) removal of biogenic substances from agricultural, forest and urbanized landscapes, promoting eutrophication and other negative consequences, remains insufficiently studied. But for the surface slope runoff, mainly spring runoff [1-3 etc.], the biogenic substances migration export by other elements of the river basin vertical hydrological structure [4], including underground runoff, usually is not analysed, assuming their contribution to be insignificant. However, very significant changes have occurred in the structure of the water balance over the past decades - the amount of surface slope runoff has significantly decreased and precipitation infiltration has increased $[5,6]$.

\section{Methodological specifics and a baseline information}

The theoretical and methodological basis of the study is founded on the idea of the river basin vertical hydrological structure [4]. The annual water-biogenic balance method is used as a tool to study its hydrochemical activity. The principle method of its calculation is given in [7]. In this article, on the example of the Linda ( $75 \%$ of the catchment area is occupied

\footnotetext{
*Corresponding author: dolgov@igras.ru
} 
by forest) and Kudma (43\%) river basins and the Kursk region territory (11\%), an attempt is made to assess the diffuse removal of biogens, to determine the ratio of natural and anthropogenic factors in it, and to identify recent trends. Along with the surface runoff from the catchment area, the contribution of underground runoff and precipitation to this process is estimated.

The data of Federal Service of Russia for Hydrometeorology and Monitoring of the Environment, Federal State Statistics Service and Federal Agency for State Registration, Cadastre, and Cartography is used as a baseline information. Along with the data on runoff and precipitation for recent years (2008-2018), the data on the runoff structure [8] for the period of normal annual runoff calculation (the early 1960s) were used. The data on the total river flow as well as on its underground and surface components were analyzed. The separation of the runoff hydrograph by types of river alimentation allowed to calculate the underground runoff. The surface component of the runoff was determined by the difference between the river and underground runoff. The source data set also includes the results of field studies carried out in the 2000s by the members of the Institute of Geography RAS (IGRAS), hydrochemical records for recent years (2008-2018), and information about the anthropogenic supply of biogens to the Linda and Kudma river catchments, obtained in the works of the IGRAS on the Federal project "Improvement of the Volga". The assessment of the components of natural biogen supply to river catchments from tree and herbal waste and nitrogen biofixation by plants was performed according to published data [1,9-11].

\section{Results and discussion}

\subsection{Contribution of individual components of the annual biogenic balance in the Linda and Kudma river basins}

Calculations have shown that in total biogen export by the Linda water flow the share of biogen removal by diffuse flow significantly prevails over their share removed by wastewater which in recent years does not exceed 1\%. The diffuse (nonpoint) removal of biogens with different elements of water runoff varies significantly over the years and depending on the seasons.

The current nitrogen anthropogenic load on the Linda basin is relatively low. It exceeds the climate nitrogen background induced by precipitation only by 1.2 times (Table 1 ). Especially significant is the phosphorus load, which exceeds eightfold the climate background. Moreover, in recent years with mineral fertilizers the Linda catchment receives almost the same amount of phosphorus as with atmospheric precipitation. Input of phosphorus from livestock is predominant (almost 7 times the climatic background), especially in recent years with a low level of fertilizer use.

A low level of mineral fertilization ( $40 \%$ nitrogen, $25 \%$ phosphorus of the peak in 1990) $[11,12]$ led to a negative balance of nitrogen and phosphorus on the arable land, due to their annual removal by crops in the 2000s. However, a significant reduction in the fertilizer use and livestock number has not led to a decrease in the removal of biogens from the Linda river catchment, on the contrary, it has even increased in recent years. This was mainly due to the climate-related increase in the flow of infiltration origin (underground and perched water).

Anthropogenic biogens input to the Kudma river catchment is significantly more than that to the Linda river catchment, and their diffuse outflow with surface and underground runoff also prevails. From the Kudma river catchment about 13\% nitrogen and 5\% phosphorus have been removed by wastewater in recent years. 
Table 1. Annual balance of biogenic substances in the Linda and Kudma river basins, $\mathrm{kg} / \mathrm{km}^{2}$.

\begin{tabular}{|c|c|c|c|c|c|c|c|c|}
\hline \multirow[b]{2}{*}{$\begin{array}{c}\text { Biogenic } \\
\text { substances }\end{array}$} & \multicolumn{6}{|c|}{ Input } & \multirow{2}{*}{\multicolumn{2}{|c|}{ Export }} \\
\hline & $\frac{\tilde{0}}{\stackrel{0}{0}}$ & 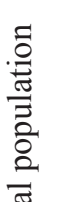 & 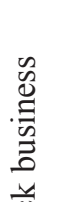 & : & 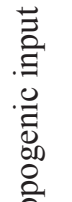 & 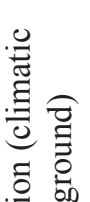 & & \\
\hline \multicolumn{7}{|c|}{ The Linda river basin } & $\begin{array}{l}\text { The Linda } \\
\text { river - v. } \\
\text { Vasilkovo }\end{array}$ & $\begin{array}{l}\text { The Linda } \\
\text { river - river } \\
\text { mouth } \\
\left(1681 \mathrm{~km}^{2}\right)\end{array}$ \\
\hline $\begin{array}{l}\text { Mineral } \\
\text { nitrogen }\end{array}$ & 42 & 20 & 232 & 80 & 374 & 325 & 280 & 212 \\
\hline $\begin{array}{l}\text { Mineral } \\
\text { phosphorus }\end{array}$ & 7 & 3 & 135 & 18 & 163 & 20 & 7 & 7 \\
\hline \multicolumn{7}{|c|}{ The Kudma river basin } & $\begin{array}{l}\text { The Kudma } \\
\text { river - Kstovo }\end{array}$ & $\begin{array}{c}\text { The Kudma } \\
\text { river - river } \\
\text { mouth } \\
\left(3246 \mathrm{~km}^{2}\right)\end{array}$ \\
\hline $\begin{array}{l}\text { Mineral } \\
\text { nitrogen }\end{array}$ & 102 & 50 & 401 & 367 & 968 & 284 & 298 & 170 \\
\hline $\begin{array}{l}\text { Mineral } \\
\text { phosphorus }\end{array}$ & 17 & 8 & 196 & 80 & 314 & 20 & 7.7 & 10.3 \\
\hline
\end{tabular}

The current phosphorus anthropogenic load on the Kudma catchment is especially high exceeding 16 times the climatic background induced by precipitation (Table 1). The nitrogen load is less -3.4 times excess.

The cattle breading and fertilization are the most significant sources of anthropogenic nutrient input to the Kudma river catchment. They make $84 \%$ nitrogen and $92 \%$ phosphorus in the total anthropogenic input. Moreover, the biogenic load induced by cattle breeding is almost the same in size as induced by crop production. The phosphorus load due to cattle breeding even twice as much.

A significant reduction in fertilizer use and farm stock, a decline of nitrogen and phosphorus in the soil of arable land did not lead to a decrease in the nutrients export from the Kudyma river catchment, on the contrary, it even grew (as in the Linda basin) due to an increase in runoff of infiltration origin (underground and perched water). Natural factors in biogens export from the Kudma river basin to the Cheboksary reservoir also prevail. Especially this is the case of nitrogen (74\%) and to a lesser extent of phosphorus $(53 \%)$. The proportion of anthropogenic load is 26 and $47 \%$, respectively.

\subsection{Modern changes in the nutrients export from the Linda and Kudma river catchments}

Compared to the mid-1970s the biogens export by surface and underground flow during the spring flood-time in the Linda basin increased by $26 \%$ in recent years (2008-2018). During this period the total flow from the Linda catchment brings to the Cheboksary reservoir 146 
$\mathrm{kg} / \mathrm{km}^{2}$ of nitrogen and $3.9 \mathrm{~kg} / \mathrm{km}^{2}$ of phosphorus. The annual removal of nutrients has also increased significantly (by more than $25 \%$, making $280 \mathrm{~kg} / \mathrm{km}^{2}$ of nitrogen and $7 \mathrm{~kg} / \mathrm{km}^{2}$ of phosphorus). The main reason is a significant increase (by $60 \%$ ) in the hydrochemical role of underground runoff - the annual nitrogen export by it has raised up to $56 \%$ and phosphorus up to $46 \%$. In recent years, the role of surface runoff in the removal of phosphorus from the catchment area remains more significant $\left(0.6 \mathrm{~kg} / \mathrm{km}^{2}\right.$ more than with underground runoff).

As for the Kudma basin the removal of biogens by surface runoff during the spring flood-time has not changed much in recent years (2008-2018). However, the role of underground runoff in their migration has increased significantly. 25\% more nitrogen and phosphorus began to flow with the underground component of the runoff. As a result, in recent years, the Cheboksary reservoir received $110 \mathrm{~kg} / \mathrm{km}^{2}$ of nitrogen and $3.8 \mathrm{~kg} / \mathrm{km}^{2}$ of phosphorus, i.e. $8 \%$ more. Especially significantly increased the annual removal of nutrients (up to $298 \mathrm{~kg} / \mathrm{km}^{2}$ of nitrogen and $7.7 \mathrm{~kg} / \mathrm{km}^{2}$ of phosphorus, 28 and $20 \%$ increase, correspondingly), mainly due to a significant increase in underground runoff (by $60 \%$ ), the contribution of which to the annual runoff of nitrogen increased to $67 \%$, and phosphorus to $56 \%$. In recent years, the river has received from each square kilometer of the catchment area an average of $104 \mathrm{~kg}$ more nitrogen with underground than with the surface runoff, and $1 \mathrm{~kg} / \mathrm{km}^{2}$ more phosphorus.

\subsection{Contribution of individual components to the annual balance of nutrients in the Kursk region}

Diffuse removal of biogenic substances from river catchments of the Kursk region significantly prevails over removal with sewage, where there are only $7 \%$ nitrogen and even less phosphorus $-3 \%$.

The calculations showed (Tables 2 and 3), that the anthropogenic input of biogens to river catchments significantly prevails over their natural input. The total amount of nitrogen input is $6792 \mathrm{~kg} / \mathrm{km}^{2}, 70 \%$ of it come due to anthropogenic load. Corresponding figures for phosphorus input are $2299 \mathrm{~kg} / \mathrm{km}^{2}$ and $95 \%$, respectively. The fertilization and farm animal waste (especially pig factory and poultry wastes) induce the highest biogenic load. A road network gains value as a source of biogens load showing a tendency to increase. The density of hard surface roads is almost 1.5 times higher than the density of the river network. The input of nitrogen from the road network is $30 \%$ higher than that with wastewater, and of phosphorus it is 7 times higher.

The natural input of biogens in recent years remains quite high and exceeds the removal of nitrogen with the river flow by 17 times and of phosphorus by 9 times. Basically, nitrogen and phosphorus are supplied to river catchments by tree and herbal waste. Atmospheric precipitation is also a significant source of their income.

Annual average export of nitrogen from the river catchments of the Kursk region is 124 $\mathrm{kg} / \mathrm{km}^{2}$, of phosphorus $-13 \mathrm{~kg} / \mathrm{km}^{2}$. The share of the underground component in the removal of nitrogen with a total annual runoff prevails and amounts to $60 \%$ (phosphorus $50 \%$ ). The removal of biogens with the surface component of the runoff is maximum in the flood period, when the discharge of nitrogen and phosphorus reaches 80 and $65 \%$ of their annual value, correspondingly.

Under the influence of mainly climatic changes, the surface component of the annual river runoff over recent years (2008-2016) has significantly decreased as compared to normal annual discharge[8] by $60-70 \%$. The underground component of the runoff has increased by $10-20 \%$. As a result, the river runoff has significantly decreased (by $30-40 \%$ ) and so has the nutrient removal. 
Table 2. The main anthropogenic components of the annual water-biogenic balance of the Kursk region, $\mathrm{kg} / \mathrm{km}^{2}$.

\begin{tabular}{|l|l|c|c|}
\hline \multicolumn{1}{|c|}{ Balance components } & Mineral nitrogen & Mineral phosphorus \\
\hline \multirow{5}{*}{ Input } & urban population & 56 & 9.1 \\
\cline { 2 - 4 } & agricultural population & 26 & 4.4 \\
\cline { 2 - 4 } & hard surface roads & 11.2 & 2.1 \\
\cline { 2 - 4 } & wastewater & 8.5 & 0.3 \\
\cline { 2 - 4 } & livestock business & 1300 & 530 \\
\cline { 2 - 4 } & mineral fertilizers & 3021 & 1510 \\
\cline { 2 - 4 } & $\begin{array}{l}\text { biofertilizers (straw, crop remains, } \\
\text { manure, cover crops, etc.) }\end{array}$ & 263 & 132 \\
\cline { 2 - 4 } & Total & 4686 & 2188 \\
\hline Export by river flow & 124 & 12.6 \\
\hline
\end{tabular}

Table 3. The main natural components of the annual water-biogenic balance of the Kursk region

\begin{tabular}{|c|c|c|c|}
\hline \multicolumn{2}{|c|}{ Balance components } & Mineral nitrogen & Mineral phosphorus \\
\hline \multirow{7}{*}{ Input, $\mathrm{kg} / \mathrm{km}^{2}$} & precipitation* & 641 & 13 \\
\hline & $\begin{array}{l}\text { rain washing from tree } \\
\text { crowns }\end{array}$ & 53 & 3.2 \\
\hline & tree waste & 443 & 67 \\
\hline & $\begin{array}{l}\text { biofixation of nitrogen in } \\
\text { the sown area }\end{array}$ & 700 & - \\
\hline & swamp vegetation waste & 27 & 1.8 \\
\hline & $\begin{array}{l}\text { meadow, pasture and } \\
\text { abandoned agricultural land } \\
\text { vegetation waste }\end{array}$ & 243 & 27 \\
\hline & Total & 2106 & 111 \\
\hline \multicolumn{2}{|c|}{ Export by the river flow, $\mathrm{kg} / \mathrm{km}^{2}$} & 124 & 12.6 \\
\hline \multicolumn{2}{|c|}{$\begin{array}{l}\text { The share of natural nutrient input in the } \\
\text { total input, \% }\end{array}$} & 31 & 5 \\
\hline
\end{tabular}

* anthropogenic factors also influence the supply of biogens with precipitation

\section{Conclusions}

The current hydroecological situation in the central part of the Russian Plain is largely conditioned by a decrease in the surface slope runoff mainly under the influence of climatic factors. Accordingly, its role in the migration of nutrients decreased. At the same time, the infiltration of precipitation into the soil has significantly increased and the role of runoff of infiltration origin (underground runoff and perched water) in the supply of nutrients to water bodies has increased.

The diffuse removal of biogens from the catchments of small and medium-sized rivers in the central part of the Russian plain in recent years (2008-2016) is 75-95\% of their total export by the river flow. On the catchment area of the side tributary of the Cheboksary reservoir, the natural component in the migration of biogens prevails, accounting for 55$75 \%$ their total removal. Due to the intensive anthropogenic load in the Kursk region, the anthropogenic input of biogens to the river catchments (70\% nitrogen and $95 \%$ phosphorus) significantly prevails over their natural input. The main negative anthropogenic factors are urbanized areas, including the road network, livestock business, mineral fertilizers (in the Kursk region), and wastewater discharges, especially directly into water bodies. 
The restoration of currently closed water balance stations and the organization of new ones will help to answer a number of still unresolved issues. The study of water quality is to play an important role in the work program of these stations.

The work was done within a State assignment of the Institute of Geography RAS No. 0148-20190007, State registration No. AAAA-A19-119021990093-8 (Kursk region) and with the financial support from the Russian Foundation for Basic Research, grant No. 18-05-00479 (the Linda and Kudma river basins).

\section{References}

1. N.I. Khrisanov, G.K. Osipov, Water Eutrophication Management (Hydrometeoizdat, St. Petersburg, 1993).

2. S.V. Yasinsky, F.N. Gurov, Water Sector of Russia, 2, 41 (2006)

3. S.A. Kondratiev, A.Yu. Bryukhanov, A.V. Terekhov, Problems of Geography, 145, 89 (2018)

4. S.V. Dolgov, N.I. Koronkevich, Izv. RAN. Ser. Geograf. 1, 7 (2010)

5. A.T. Barabanov, S.V. Dolgov, N.I. Koronkevich, V.I. Panov, A.I. Petelko, Eurasian Soil Sci. 1, 66 (2018)

6. S.V. Dolgov, N.I. Koronkevich, E.A. Barabanova, Water Sector of Russia, 4, 78 (2018)

7. S.V. Dolgov, N.I. Koronkevich, Izv. RAN. Ser. Geograf. 5, 43 (2019)

8. Water resources and water balance of the territory of the Soviet Union (Hydrometeorological publishing house, Leningrad, 1967)

9. L.E. Rodin, N.I. Bazilevich, The dynamics of organic matter and the biological cycle in the main types of vegetation of the globe (Nauka, Moscow-Leningrad, 1965)

10. L.E. Rodin, N.P. Remezov, N.I. Bazilevich, Guidelines for the study of dynamics and the biological cycle in phytocenoses (Nauka, Leningrad, 1968).

11. A.I. Abramov, E.A. Krymova, FSBICenter for Agrochem. Ser. "Nizhny Novgorod" (2014), https://agrohim-nn.ru/stati/47-sostoyanei-plodorodiya-pakhotnykh-zemel-vnizhegorodskoj-oblasti.html.

12. Nizhny Novgorod region in numbers. 2017: Brief statistical compilation (Nizhny Novgorodstat, Nizhny Novgorod, 2017) 